\title{
Iniciaremos uma nova etapa
}

O processo editorial da Journal of Multidisciplinary Dentistry teve início em 1997 com a criação da Innovations Magazine e posteriormente com a Innovations Journal em 1999 que tinham como objetivo divulgar equipamentos e técnicas em Odontologia.

Em 2006 o título é alterado para Innovations Implant Journal: Biomaterials and Esthetics, tornando-se um periódico com um perfil de atender os profissionais das especialidades de Implantodontia, Biomateriais e Estética relacionadas com o planejamento envolvendo implantes osseointegrados.

Buscando divulgar conhecimentos em todas as especialidades odontológicas, em 2008, o foco da Innovations Implant Journal: Biomaterials and Esthetics é a multidisciplinariedade. São formados o conselho editorial científico e os comitês editoriais internacional e nacional, definidas a publicação de artigos originais, de revisão de literatura e relato de caso e a periodicidade quadrimestral. A partir de 2009 é publicada no formato online com acesso aberto.

Hoje, 2020, a Journal of Multidisciplinary Dentistry é uma revista que tem como objetivo oferecer conhecimento científico atualizado por meio de pesquisas, revisões de literatura e sistemáticas, casos clínicos nas diversas especialidades da Odontologia. Assim, reunindo artigos científicos e apresentando em formato digital aberto, acreditamos que a leitura será agradável e contribuirá para a nossa profissão.

Queremos compartilhar com todos os especialistas, o sucesso do lançamento desta revista e agradecer a todos os autores que contribuíram com seus trabalhos científicos.

Prof. Dr. José Fernando Castanha Henriques Editor 